\title{
REGIONAL EVOLUTION AND WAVES OF GROWTH: A KNOWLEDGE-BASED PERSPECTIVE
}

\begin{abstract}
The evolution of a regional economy and its competitiveness capacity may involve multiple independent trajectories through which different sets of resources and capabilities evolve together. However, there is a dearth of evidence concerning how these trends are occurring across the globe. Based on the underlying tenets of the streams of research relating to regional competitiveness, knowledge cities/regions, and knowledge-based urban development, this paper seeks to present an empirical approach to establishing such evidence in relation to the recent development of the globe's most productive regions from the viewpoint of their growth trajectories and the particular form of growth they are experiencing. The aim is to uncover the underlying structure of the changes in knowledge-based resources, capabilities and outputs across regions, and offer an analysis of these regions according to an uncovered set of key trends. The analysis identifies three key trends by which the economic evolution and growth patterns of these regions are differentiated - namely the Fifth Wave Growth, the Third \& Fourth Wave Growth, and Government-led Third Wave Growth. Overall, spectacular knowledge-based growth of leading Chinese regions is evident, highlighting a continued shift of knowledge-based resources to Asia. In addition, a superstructure is observed at the global scale, consisting of two separate continuums that explicitly distinguish Chinese regions from the rest in terms of regional growth trajectories.
\end{abstract}

Keywords: Waves of growth; Knowledge-based development; Knowledge city; Knowledge region; Regional competitiveness

\section{Introduction}

The evolution of a regional economy capacity may involve multiple independent trajectories through which different sets of resources and capabilities evolve together. However, there is a dearth of evidence concerning how these trends are occurring across the globe. A number of theories, including agglomeration, industrial districts and clusters, as well as innovation systems, attempt to explain the way in which resources are combined and productivity is enhanced within a regional economy. In general, these theories suggest a number of factors, such as industry and industry structure, firm type and the geographical range of external economies, to explain regional economic evolution, with them all highlighting the multiple trajectories that regions may follow in their development (Markusen, 1996; Phelps and Ozawa, 2003; Iammarino and McCann, 2006). Yet, while a large number of extant empirical studies resting on these theories are informative and useful in their own right, they are not always without shortcomings in light of the aim of uncovering an underlying structure of economic evolution and development across regions.

This paper seeks to present evidence in relation to the recent development of the globe's most productive regions from the viewpoint of their growth trajectories and the particular form of growth they are experiencing. The aim is to uncover the underlying structure of the changes in knowledge-based resources, capabilities and outputs across regions, and to offer an analysis of these regions according to an uncovered set of key trends. From these trends the paper identifies that regions are experiencing differing 'waves of growth' related to their overall economic evolution. 
Whilst a significant number of studies are designed to account for a specific dependent variable, such as gross domestic product (GDP) as a measure of economic output, or patents as a measure of innovation. This is typically achieved through the identification of a linear combination of other variables, which maximizes the proportion of the variance of the dependent variable they seek to explain. However, such accounting is different in its purpose and result from approaches that seek to identify a set of commonalities across variables. When variables represent the growth of resources, capabilities and outputs of regional innovation systems and economies, the commonalities identified across these variables may suggest processes of co-evolution across regions.

A further limitation of many extant studies is the lack of a common framework and dataset that is applicable to an analysis of regions across the globe. Empirical findings on innovation systems are typically initially generated on the basis of regions selected from a particular nation or continental bloc, rather than a fuller global coverage, resulting in a lack of harmony in terms of the frameworks employed, or the capability to provide regional comparisons that uncover regional trends across the globe (Doloreux and Parto, 2005). This paper seeks to go some way to overcoming this particular shortcoming by examining the globe's most productive regions. This facilitates a better understanding of the connections between knowledge-based development and the fundamentals of economic development, such as job creation, at a regional level (Vivarelli and Pianta, 2000; Döpke, 2001).

The analysis presented in this paper is principally related to the lineage of research focused on examining regional and urban competitiveness (Begg, 1999; Huggins, 2003; Boschma, 2004; Kitson et al., 2004; Huggins and Izushi, 2007; Camagni, and Capello, 2012). This stream of research seeks to understand and measure the nature of economic development and growth differentials across regions and cities, as a means of analysing the economic trajectories and evolution of regions (Huggins and Izushi, 2007; 2013). The notion of regional competitiveness is directly associated with the concepts of knowledge cities (Carrillo, 2004; 2006; Yigitcanlar et al., 2008), knowledge regions (Lönnqvist et al., 2013), and knowledge-based urban development (Knight, 1995; 2008; Ovalle et al., 2004; Kunzmann, 2009; Yigitcanlar, 2009; Yigitcanlar and Lönnqvist, 2013). Both the competitiveness and knowledge city concepts take 'knowledge' as their key construct for understanding the means and modes of regional and city development (Huggins and Izushi, 2007; Yigitcanlar, 2009), with an explicit focus on identifying the knowledge assets of regional and city environments (Malecki, 2004, 2007; Kunzmann, 2008; Lönnqvist et al., 2013). The knowledge city and knowledge-based urban development schools of thought encompass the knowledge construct within a framework that seeks to integrate the economic, social, and environmental assets and factors underpinning development. Within this framework, regional and urban competitiveness forms a key component of the economic dimensions of knowledge city and knowledge-based urban development analysis (Yigitcanlar, 2009; 2010).

Both regional competitiveness research and knowledge-based urban development research have undertaken analyses that incorporate the benchmarking of a range of similar and complementary economic indicators (Huggins, 2003; 2010; Yigitcanlar 2010; Yigitcanlar and Lönnqvist, 2013). More specifically, both the regional competitiveness and knowledge city concepts acknowledge that the key drivers of sustained economic performance are usually considered to consist of the enhancement of knowledge and creativity through clusters of firms and complementary knowledge-based organizations (Huggins and Izushi, 2007; Yigitcanlar, 2009; 2010; Huggins and Thompson, 2013). In essence, they are both rooted in the notion that the sources of high rates of economic performance and subsequent growth stem from the role that the production, distribution, and use of knowledge play within and across economies. Therefore, this paper seeks to contribute to the knowledge city and region 
research by providing a method, analytical framework, and empirics for better understanding the economic dimensions of knowledge-based urban development.

\section{Waves of growth and the co-evolution of resources, capabilities and outputs}

Based on Nikolai Kondratieff's work $(1926,1935)$ on the cycle of major economic crises at approximately half-century intervals, Joseph Schumpeter (1939) wrote that each of the 'long waves' of economic development started with a new group of innovations, which resulted in the creation of new industries. According to this long wave theory, the first Kondratieff wave was based on iron and cotton industries, spanning the period of 1785-1842. This is followed by the second wave (1843-1897) with steel, machine tools, and ship building as its key industries. The twentieth century includes two long waves: the third wave (1896-1947) based on automotive, electrical engineering, and chemicals; and the fourth wave (1948-) for which growth was propelled by electronics, computers, communications, aerospace, and producer services (Hall and Preston, 1988). Whilst the timing of the fourth wave's end and the fifth wave's beginning remains open to debate, ranging from the early 1990 s to around the turn of the century, there is much agreement as to the central role played by the digital revolution and the Internet as the enabling innovation underpinning the fifth wave, creating a large increase in informational service jobs, as well as a demand for new infrastructural network development (Hall and Preston, 1988; Wymbs, 2004; Devezas et al., 2005; Linstone and Devezas, 2012).

Based on the view of a region as an interlinked system, innovation systems theory proposes the co-evolution of its components (Freeman, 2002; Borrás, 2004; Heidenreich, 2004). However, there is little evidence concerning the key dimensions through which a region's resources, capabilities and outputs evolve together, and potentially represent an association with one of the underlying key waves of growth indicated above. Doloreux and Parto (2005) find that studies of regional innovation systems are typically designed either to offer 'snapshots' of individual systems, or to specify desirable factors and mechanisms for promoting innovation through a comparison of regions.

Surveying approximately 200 studies of regional innovation systems, Carlsson (2007) finds that slightly more than half are empirically oriented, focusing mostly on a particular region or multiple regions, with also more than half of the empirical studies focusing solely on regions within Europe. A significant proportion of early studies are qualitative case studies that aim to provide a narrative on the intangible dimension of the knowledge circulation and learning (Doloreux and Parto, 2005). More recently, a growing body of literature takes a quantitative approach, such as a knowledge production function model, to investigate regional innovation systems (Fritsch, 2002; Bilbao-Osorio and Rodríguez-Pose, 2004; Buesa et al., 2006; Crescenzi et al., 2007; Rodríguez-Pose and Crescenzi, 2008; Buesa et al., 2010).

The aim of these more quantitative studies is to account for a specific variable selected $a$ priori, such as patents or GDP, and to examine the effects of variables representing innovation system characteristics. In these studies, variables are often measured only at one point in time, thus failing to show change over time. Such analyses are different in their aims and findings from approaches seeking to identify the co-evolution of the key components of regional economic systems. An exception to this is a recent study of four selected knowledgebased sectors across German regions by Buerger et al. (2012), who investigate the coevolution of patents, $R \& D$ and employment, analyzing panel data for these three variables with a vector auto regression model. The study finds that past innovation growth, as measured by patents, is associated with the subsequent growth of employment in certain 
sectors, suggesting that, in these sectors: the employment gains of innovators are greater than the losses of non-innovators; and, the labor-saving effects of process innovations are compensated for by other positive effects resulting from these innovations. However, the study focuses on a relatively small number of variables in selected knowledge-based sectors, leaving their relationships with other less knowledge-intensive sectors unexplored. Furthermore, the study concerns regions in a single nation. This latter point of limited regional coverage is shared by most qualitative case studies examining a single or only a few regions, as well as econometric studies which examine regions in a single nation (Buesa et al., 2006), in Europe (Fritsch, 2002; Bilbao-Osorio and Rodríguez-Pose, 2004; Rodríguez-Pose and Crescenzi, 2008; Buesa et al., 2010) or across both Europe and the US (Crescenzi et al., 2007).

There is, therefore, a gap in the literature in terms of identifying the co-evolution of regional economic system components at a global level. In order to achieve this, the analysis presented here seeks to combine theories of knowledge production and innovation systems (Fritsch, 2002; Cooke, 2004; Buesa et al., 2006; Buesa et al., 2010) with the wider economic systems underlying the production of goods and services, allowing an examination of the interrelationships among these components at a regional level. In particular, the impact of knowledge-based sectors upon the rest of their regional economy is likely to be influenced by how closely the former is tied to more traditional, less knowledge-intensive economic activity within a region through knowledge spillovers, as well as through input-output linkages and the multiplier effects of demand creation (Adams, 1990; Rodríguez-Pose and Crescenzi, 2008).

\section{Analytical framework}

In order to empirically analyze knowledge-based development at a regional level in this section we develop an analytical framework and explain the rationale underlying its conceptualization. As shown in Figure 1, the framework consists of two domains, both of which are underpinned by the stock of knowledge or technology. One domain (the top half in the figure) represents the production of goods and services. A standard set of production factors - physical capital, labor and human capital — is combined with technology. The other domain (the bottom half) represents the production of new knowledge, which in turn gives rise to productivity growth. Key activities in this domain are R\&D within business firms and research within the science base (i.e. universities and government laboratories). Unlike the production of goods and services, the factors of knowledge production consist of physical capital and human capital (as the hand-eye co-ordination of labor by definition does not count here).

The activities in the two domains are linked to one another through various feedback loops (Kline and Rosenberg, 1986). A growing body of studies, particularly the innovation system literature, identifies various linking mechanisms which influence how individuals and firms relate to each other and learn. Lastly, part of the value created in the production of goods and services is invested in the factors in both domains. Such investment is crucial to the long-term sustainability of productivity.

The framework employs a set of 20 indicators (which are presented in Figure 1). In the domain of new knowledge production, we choose the number of employees in five high-tech sectors as proxies for the human capital devoted to innovation. A number of studies attempt to classify sectors based on criteria related to research and technology intensity (Lee and Has, 1996). We use the Eurostat (the European Commission's statistical office) scheme of industry 
classification, which was developed in collaboration with the OECD (Hatzichronoglou, 1997; Laafia, 1999). We classify into five groups those sectors considered by Eurostat as 'highertech manufacturing sectors', 'medium-high-tech manufacturing sectors' and 'high-tech service sectors'. The five groups are: IT and computer manufacturing; high-tech services; biotechnology and chemicals; instrumentation and electrical machinery; and automotive and mechanical engineering.

Other technology-input measures include R\&D expenditures performed by the business and government sectors. Compared with corporate R\&D, the impact of public sector R\&D is less direct in its route in terms of both diffusion and timing. Nonetheless, there is evidence that spillovers from public sector R\&D raise an economy's productivity (Jaffe, 1989; Adams, 1990). Due to issues of data availability, $R \& D$ expenditures performed by the government sector are used as an indicator of public sector R\&D.

As for technology-output measures, we use the number of patents granted. The propensity to patent is known to vary widely across industries, with many patents turning out to be worthless, while a few are extremely valuable (Pavitt, 1982). Yet, patent statistics are the most widely available data concerning research outputs (Griliches, 1990). Furthermore, there is some evidence that suggests a close association between patents and other productivitybased measures at the national and regional level (Fagerberg, 1996; Acs et al., 2002).

With regard to linking mechanisms, we use private equity investment capital as a proxy of the availability of funds for knowledge-based start-up firms. Private equity funding is often concentrated in small or medium-sized firms, including venture capital and start-up investments, which tend to be in knowledge-based activities. In addition, three indicators of Internet-based infrastructure are employed: numbers of Internet hosts, secure servers, and broadband access.

In the production of goods and services domain, we include the employment rate (defined as one minus the unemployment rate) and the economic activity rate (defined by the ratio of the labor force to the working-age population) in our analysis. While these indicators show an economy's capacity to draw and develop a greater amount of human capital out of its population, higher rates also tend to suppress average productivity levels, with there being an increasing proportion of low-wage, low-productivity jobs in places with relatively high activity rates. Furthermore, in the face of the global challenge from low-cost producers, those industries where productivity remains low compete by primarily using low-cost and lowskilled labor (Dunford, 2005). This phenomenon is particularly evident in those countries with deregulated labor markets (such as the US), which generally show a greater capacity to use a larger part of the labor pool (Crouch et al., 1999).

We also include the number of managers as a proxy of human capital. Although this is hardly a perfect indicator of human capital, a similar indicator is used in international studies of the labor market (OECD, 1994). The wages of managers are generally higher than those of other occupations, reflecting the greater amount of investment made in education and training.

For indicators of the long-term sustainability of productivity, we include public expenditures on primary and secondary education and higher education. There is a sequential interaction between a region's education and training system and its stock of high-skilled workers. A region's employment and career prospects, as well as the socioeconomic background of pupils and the quality of schooling, influence the rate of enrolment in education. Enrolment, in turn, determines the region's workforce skills, productivity and economic performance (Bradley and Taylor, 1996). Public investment in education plays an 
important role in this sequential cycle, particularly improving the quality of local schooling over time.

Lastly, we adopt labor productivity, gross domestic product (GDP) and mean gross monthly earnings as indicators of regional economic performance.

\section{[INSERT FIGURE 1]}

To remove effects of the size of each region analyzed, we take per capita figures for the following variables: GDP, R\&D expenditures performed by business sector and government sector, patents granted, private equity investment capital, Internet hosts, secure servers, broadband access, and public expenditures on primary and secondary education, and higher education. Employment in the five high- or medium-high- tech industries and number of managers are based on a per total regional employment basis.

\section{Data and analysis}

The analysis reported in this paper covers 117 regions for which data for all 20 indicators described above are available at two points, 2000/01 and 2010/11, or equivalent years. Of the 117 regions contained in the dataset there are 54 representatives from North America, 41 from Europe, and 22 from Asia and Oceania. Of the North American regions, 48 are US and 6 are Canadian. Among the Asian and Oceania regions, there are 7 Chinese regions (Taiwan is also included separately), 9 Japanese regions, and 3 Australian regions, as well as New Zealand and Singapore. The full list of 117 regions analyzed is shown in Appendix 1.

The unit of analysis for each nation is selected in such a way to provide as high a degree of consistency as possible across the nations under analysis. For the US, regions are based on the metropolitan statistical areas (MSAs) classification. As defined by the US Census Bureau, MSAs consist of an area with a substantial population center and adjacent counties having a high degree of economic homogeneity, which is, compared with counties, cities and states, more robust for economic analysis as they reflect the boundaries of clusters of firms in related industries. The European regions are based on the European Union's definition of regional units, covering the so-called NUTS-1 territories. The Canadian regions are based on their defined provincial units. The Asian and Oceanic regions consist of prefectures in Japan and are defined by city or provincial boundaries for most other nations (for example, provinces for China), as well as the inclusion of Taiwan, Singapore, and New Zealand as region-states. For each of the 20 indicators, we measure their compound annual growth rates for the period $2000 / 01$ to $2010 / 11$ or an equivalent period.

The annual compound growth rates of the 20 indicators may overlap with one another and to identify such overlapping across the variables we adopt factor analysis in our methods. Factor analysis reduces an original set of variables into a smaller number of composite variables called 'factors'. Each factor is a latent dimension underlying the original set of variables presented as a condensed statement of the relationships between them. Furthermore, the position of a region in each dimension is given as a score called a factor score. The factors identified are orthogonal with one another and accordingly factor scores are uncorrelated across factors. With the use of the Anderson-Rubin method of estimation, factor scores have a mean of zero and a standard deviation of one. As for the extraction of factors and rotation of a factor matrix, we use the maximum likelihood method and the varimax method respectively. The maximum likelihood method provides the best statistical procedure as a goodness-of-fit test of the factor model (Gorsuch, 1983). In the factor analysis, four variables - the growth rates for gross domestic product per capita, public expenditures on 
primary and secondary education, secure servers, and broadband access — are dropped as they are found to conform to Heywood case variables. ${ }^{1}$

After these variables are removed, a reliable set of factors is obtained using the Schwarz (1978) method to determine the number of factors. A goodness-of-fit test of the factor model obtains the chi-squared value of 196.06 and the significance value of 0.00 , showing a highly satisfactory level. Utilizing the factor score of each region, cluster analysis is then undertaken to establish a grouping of regions. Cluster analysis is the most commonly used technique for identifying groups of homogeneous objects within the population. This is achieved by maximizing the homogeneity of objects within the clusters while also maximizing the heterogeneity between the clusters. The Euclidian distance using their factors scores as coordinates defines similarity between regions. For a hierarchical clustering algorithm the average linkage procedure is adopted. The number of clusters is decided by examining changes in the agglomerative coefficients (Hair et al., 2010).

\section{Regional evolution: empirical results}

This section of the paper outlines the key changes in the indicators contained within the analytical framework across the examined regions.

\subsection{Growth rates}

The average growth rates of 117 regions for the 20 indicators and their averages by nation or continental bloc - the US, Europe, Canada, Australia, Japan, and China - are shown in Table 1. When the averages of all regions are examined, per capita gross domestic product hits an annual growth rate of 4.18 per cent. The majority of this growth comes from the growth of labor productivity, which shows an annual growth of 2.95 per cent, whilst the rest derives from the growth of labor force participation relative to the total population. Economic activity rates grew at an annual rate of 1.25 per cent. In contrast, the employment rate dropped by 0.24 per cent on average. Thanks to the growth of labor productivity, mean gross monthly earnings grew at an annual rate of 5.67 per cent. However, the number of managers per 1,000 employees declined by 1.30 per cent annually, most likely due to the reduction of middle managers through the delayering of corporate hierarchies.

In terms of knowledge creation, the number of patents registered per 1,000 inhabitants grew by 11.39 per cent annually, which is an indication of a number of factors including changes made in the regime of patenting in the 1990s and the tactic of patent harvesting employed by a growing number of corporations, as well as a deepening of the knowledge economy. As for the inputs of knowledge creation, per capita expenditures on R\&D performed by government dropped by 9.20 per cent annually, reflecting recent austerity measures taken by governments in many nations and regions. By contrast, per capita expenditures on R\&D performed by business continued to grow, with an average annual growth rate of 7.13 per cent.

Changes in employment in high-technology industries vary significantly across the five sectors examined. The growth of employment in instrumentation and electrical machinery

\footnotetext{
${ }^{1}$ In factor analysis, the variance of each variable is divided into the variable's unique variance and the rest explained by latent factors. A Heywood case refers to the appearance of a negative estimate of the unique variance or the convergence of an estimate to zero, which is practically implausible. This computational anomaly often arises from the presence of one or more high correlations of variables and the attempt to extract more factors than are present (Bartholomew and Knott, 1999, pp. 62-63).
} 
was the fastest, showing an annual growth rate of 4.78 per cent, followed by 2.77 per cent for high-tech services. By contrast, the other three sectors exhibit a decline in their employment per 1,000 employees. IT and computer manufacturing was hit the hardest with a decline of 5.55 per cent annually. This was followed by biotechnology and chemicals, which declined by 2.05 per cent and automotive and mechanical engineering by 0.53 per cent.

As for public educational expenditures per inhabitant, expenditures on higher education grew by 5.75 per cent, whilst expenditures on primary and secondary education showed a more modest growth of 2.77 per cent annually. The amount of private equity investment, or venture capital, per inhabitant grew by 12.71 per cent annually, second only to the three ICT infrastructure indicators - Internet hosts, secure servers, and broadband access - which showed the fastest rates of growth, 39.44 per cent, 42.55 per cent, and 21.47 per cent respectively.

\section{[INSERT TABLE 1]}

Against this overall picture, regions in the US, Europe, Canada, Australia, Japan, and China present differentiated patterns of growth. In terms of per capita GDP, the growth performance of Chinese regions is spectacular with an average rate of 7.60 per cent, which is in stark contrast to the rest of the regions analyzed. Five Chinese regions-Beijing, Jiangsu, Tianjin, Shandong, and Guangdong - are in the top 10 of the fastest growing regional economies along with Singapore, British Columbia, Bratislavsky, Ontario, and Estonia. In contrast, regions in the US, Canada, Europe, Australia, and Japan grew, on average, at nearly half of the average rate achieved by Chinese regions. The slowest-growing regions are predominantly in the US, with six regions (Buffalo-Niagara Falls, Rochester, Grand RapidsWyoming, Richmond, Louisville, and Sacramento-Arden-Arcade-Roseville) ranking in the bottom 10, along with Alberta, Quebec, Saskatchewan, and Emilia-Romagna. Of these, Buffalo-Niagara Falls, Rochester, and Alberta have shown a fall in per capita GDP.

\subsection{Productivity, earnings, and activity rates}

Labor productivity growth has also been most pronounced among Chinese regions, showing an average rate of 4.89 per cent. However, the gaps with the rest of the regions, particularly European regions, are smaller than the gaps observed in per capita GDP growth. This is in large part due to a significant proportion of GDP growth in Chinese regions deriving from the inflow of labor from other parts of the nation, which is shown in the fast pace of growth in Chinese economic participation rates. Of the rest of the regions analyzed, European and Australian regions have shown relatively fast growth rates, whilst Japanese regions showed the slowest pace. The fastest rate of labor productivity growth was recorded by Bratislavsky and Praha, two East European regions, with the rest of the top 10 regions consisting of Tianjin, Région de Bruxelles-Capitale, Singapore, London, Beijing, Shandong, Tokyo, and Estonia. By contrast, the bottom 10 regions include seven US regions (BuffaloNiagara Falls, Rochester, Hartford-West Hartford-East Hartford, Richmond, Grand RapidsWyoming, San Antonio, and Sacramento-Arden-Arcade-Roseville), two Dutch regions (Noord-Nederland and Zuid-Nederland), and one Japanese region (Kanagawa).

Earnings growth shows a significantly different pattern from those of per capita GDP and labor productivity growth. The Chinese regions have experienced a decline by 2.40 per cent annually, whilst the other nations or continental blocs have shown, on average, positive growth, with the US and Japanese regions, in particular, showing a strong performance. Latvia and Estonia are the best performers in this indicator, followed by five US regions (Salt Lake City, Houston-Sugar Land-Baytown, Nashville-Davidson-Murfreesboro, Milwaukee- 
Waukesha-West Allis, and Virginia Beach-Norfolk-Newport News), two Japanese regions (Kanagawa and Kyoto), and Etelä-Suomi (Finland). The bottom 10 regions are dominated by Chinese regions (Beijing, Guangdong, Tianjin, Shanghai, and Zhejing), along with Israel, Taiwan, Sydsverige (Sweden), and two Australian regions (Victoria and New South Wales).

Changes observed in economic activity rates are relatively small with the exception of the Chinese regions. As mentioned earlier, the strong performance of the Chinese regions in GDP growth comes from the influx of labor into these regions from others part of the nation, leading to a significant increase in economic activity rates. All seven Chinese regions are ranked in the top 10, followed by three US regions (Virginia Beach-Norfolk-Newport News, Miami-Fort Lauderdale-Miami Beach, and San Antonio). The Canadian and European regions are weak performers on average for this indicator.

Of the 117 regions analyzed, 20 regions suffered a fall in economic activity rate, with a great majority of them being located in Europe and Canada. In particular, six regions in the Nordic nations (Västsverige, Stockholm, Småland med Öarna, and Sydsverige in Sweden, Etelä-Suomi in Finland, and Norway) rank in the bottom 10 regions, along with Ontario and three US regions (Cleveland-Elyria-Mentor, Salt Lake City, and Milwaukee-Waukesha-West Allis).

Across the 20 indicators, employment rates show the smallest change in percentage terms. The annual rate of change ranges from 0.14 per cent in the Australian regions to -0.50 per cent in the US regions. The largest improvement is made by Israel ( 0.55 per cent $)$, with Berlin ( 0.52 per cent) and Bratislavsky ( 0.34 per cent) being the second and third best performers. Theese are followed by Singapore, Schleswig-Holstein, Quebec, Osaka, Niedersachsen, Zhejing, and Western (Australia). The bottom 10 regions on this indicator are seven US regions (Las Vegas-Paradise, Detroit-Warren-Livonia, Sacramento-ArdenArcade-Roseville, Tampa-St. Petersburg-Clearwater, Hartford-West Hartford-East Hartford, Charlotte-Gastonia-Concord, and Jacksonville), two Spanish regions (Comunidad de Madrid and Noreste), and Southern and Eastern in Ireland. Las Vegas-Paradise, Comunidad de Madrid, and Southern and Eastern (Ireland) suffered an annual rate lower than -1.00 per cent.

\subsection{Human capital and innovation}

The number of managers per 1,000 employees is another indicator in which the Chinese regions showed the weakest performance. On average, the Chinese regions showed the biggest fall on this indicator, followed by the Canadian, US, and Japanese regions. The fall in

the Chinese regions is most likely due to the massive inflow of labor across regions, which filled newly created low-level, non-managerial positions. By contrast, the fall in the Canadian, US, and Japanese regions appears to derive from the flattening of corporate organizational hierarchies, which cut back middle management positions. Against the trend, the European and Australian regions exhibit an increase overall, with the top 10 regions being predominantly European, including Saarland, Schleswig-Holstein, Nordrhein-Westfalen, and Niedersachsen in Germany, Lazio and Emilia-Romagna in Italy, Småland med Öarna (Sweden), Switzerland, Région de Bruxelles-Capitale, and Lithuania. The bottom 10 regions include four Chinese regions (Tianjin, Shanghai, Guangdong, and Jiangsu) along with WestNederland, Bratislavsky, Közép-Magyarország, Île de France, and Noreste and Comunidad de Madrid.

Growth rates for patent registrations show that Chinese regions have seen the greatest improvement. The fastest ten growth rates include seven Chinese regions, followed by three Japanese regions: Aichi; Toyama; and Tochigi. In contrast, North American regions, on 
average, achieved the slowest growth. With the exception of London, which suffered the fastest pace of decline ( -3.72 per cent), the bottom 10 regions are dominated by North American regions, including Memphis, Nashville-Davidson-Murfreesboro, Indianapolis, Columbus, Cincinnati-Middletown, Cleveland-Elyria-Mentor, and Milwaukee-WaukeshaWest Allis in the US, and Manitoba and British Columbia in Canada, all of which have seen a fall on this indicator.

In terms of $R \& D$ expenditures, those regions in receipt of the biggest increases in $R \& D$ expenditures performed by government are regions in Japan and Europe. The top three regions are Swedish (Småland med Öarna, Sydsverige, and Västsverige), followed by four Japanese regions (Shiga, Kyoto, Toyama, and Shizuoka), Zuid-Nederland in Netherlands, Noreste in Spain, and Singapore. Conversely, US, Canadian, and Australian regions have seen a dilution of government R\&D investment. In particular, the drop in government R\&D investment was high in the US regions, which occupy the bottom 10 positions (Hartford-West Hartford-East Hartford, Kansas City, Buffalo-Niagara Falls, Rochester, Minneapolis-St. PaulBloomington, St. Louis, Pittsburgh, Seattle-Tacoma-Bellevue, Louisville, and Las VegasParadise).

As for R\&D investment by businesses, the Australian and Chinese regions have seen by far the strongest growth on the whole, with the biggest growth occurring in Western Australia and Victoria in the former, and Shandong, Jiangsu, Zhejing, and Tianjin in the latter. The other top 10 regions are Estonia, Singapore, Raleigh-Cary, and Alberta. Of the 117 regions, eight regions have seen a drop in business R\&D investment, including Baltimore-Towson and Seattle-Tacoma-Bellevue in the US, Ontario and Manitoba in Canada, Kanagawa and Osaka in Japan, Bratislavsky in Slovak Republic, and Beijing in China. Västsverige and Stockholm in Sweden are the two other regions in the bottom 10 regions, with both only showing a marginal increase in investment.

\subsection{Industrial development}

As shown by Table 1, there is significant volatility in employment change across the socalled knowledge-based sectors. In instrumentation and electrical machinery, Chinese and European regions have seen strong growth, with the top 10 spots occupied by Jiangsu, Zhejing, and Shandong (China), Estonia, Ostösterreich (Austria), Lazio (Italy), Stockholm (Sweden), Région de Bruxelles-Capitale (Belgium), Etelä-Suomi (Finland), and ZuidNederland (Netherlands). In contrast, a significant proportion of US and Japanese regions have seen a decline in these sectors. With the exception of Switzerland, all the bottom 10 regions are located in the US, including Memphis, Louisville, Baltimore-Towson, NashvilleDavidson-Murfreesboro, St. Louis, Atlanta-Sandy Springs-Marietta, Charlotte-GastoniaConcord, San Antonio, and Kansas City.

In automotive and mechanical engineering sector, a majority of the regions have seen a decline of employment as a proportion of total employment. Those regions showing growth are predominantly European and Chinese, with the top 10 regions including Zhejing, Jiangsu, Shandong, and Guangdong in China, as well as Bratislavsky, Stockholm, Västsverige, Région de Bruxelles-Capitale, Saarland, and Norway. As for the regions that have been hit hardest, Beijing is the worst with an annual change of -23.54 per cent. Aside from the Chinese capital, those regions suffering the fastest pace of decline are predominantly in the US, including Washington-Arlington-Alexandria, Nashville-Davidson-Murfreesboro, Louisville, AtlantaSandy Springs-Marietta, St. Louis, San Jose-Sunnyvale-Santa Clara, Columbus, BuffaloNiagara Falls, and Kansas City. 
In a similar vein, less than one third of the regions have seen employment growth in biotechnology and chemicals. Chinese regions are the best performers in these sectors, with Jiangsu, Shandong, Zhejing, and Guangdong ranking in the top 10. Canadian regions also gain in these sectors, with Saskatchewan and Manitoba in the top 10 positions. Although the average of the US and European regions is negative, some have performed well, with Région de Bruxelles-Capitale, Saarland, Minneapolis-St. Paul-Bloomington, and Île de France occupying the other top 10 spots. Of those regions, which have seen a fall of employment in the sectors, the worst 10 include seven US regions (Richmond, Virginia Beach-NorfolkNewport News, Charlotte-Gastonia-Concord, Columbus, Nashville-Davidson-Murfreesboro, Rochester, and San Antonio), two Australian (New South Wales and Victoria), and New Zealand.

As mentioned earlier, of the five knowledge-based sectors, IT and computer manufacturing was hit hardest in terms of the share of employment, with only 24 regions showing positive growth rates. Regions in China gained most, which gives a strong indication of the extent to which employment has become increasingly concentrated in key locations. The top 10 regions include four Chinese regions (Jiangsu, Shandong, Zhejing, and Guangdong) along with Jacksonville and Louisville, Saarland, Switzerland, Taiwan, and Praha. Over 30 regions have witnessed a double-digit fall of employment share in percentage terms annually. Of these, those hardest hit include Virginia Beach-Norfolk-Newport News, Nashville-Davidson-Murfreesboro, Baltimore-Towson, Sacramento-Arden-ArcadeRoseville, Charlotte-Gastonia-Concord, Houston-Sugar Land-Baytown, and San Antonio in the US, as well as Saskatchewan, Manitoba, and Zuid-Nederland.

As for high-tech services, the regions analyzed are relatively evenly split into those 57 regions that have gained and those 60 that have lost in terms of employment share. The pattern is somewhat surprising, as one might expect more widely spread growth resulting from the increased deindustrialization of advanced regional economies. However, the growth in the offshoring of high-technology services in many advanced regions appears to have dampened employment growth. Of the former group, 13 regions achieved double-digit annual growth. The top 10 includes five Chinese regions (Zhejing, Shandong, Tianjin, Shanghai, and Guangdong) and three Australian regions (New South Wales, Western, and Victoria), as well as Région de Bruxelles-Capitale and Switzerland. The worst performing regions are Vlaams Gewest, Shiga, and Kanagawa, followed by two Dutch regions (Noord-Nederland and WestNederland), four US regions (Chicago-Naperville-Joliet, San Antonio, Atlanta-Sandy Springs-Marietta, and Houston-Sugar Land-Baytown), and Lombardia.

\subsection{Knowledge sustainability and finance}

In terms of growth in public expenditure on primary and secondary education, the great majority of the analyzed regions recorded an increase, led by Irish, Chinese, and US regions. The top 10 regions include Southern and Eastern (Ireland), Shandong, Jiangsu, Zhejing, Orlando-Kissimmee, Washington-Arlington-Alexandria, Phoenix-Mesa-Scottsdale, and Las Vegas-Paradise, as well as Latvia and Singapore, which all have recorded double-digit annual growth rates. By contrast, only 12 regions have seen a fall on this indicator, including three Chinese regions (Beijing, Tianjin, and Guangdong) and all nine Japanese regions analyzed.

In a similar vein, except for five regions, all analyzed regions recorded an increase in expenditure on higher education. The fastest growth has been achieved by Chinese and Canadian regions, with all seven Chinese regions and Ontario ranking in the top 10, along with Southern and Eastern (Ireland) and Praha. As for those regions experiencing falls in 
expenditure, they include Buffalo-Niagara Falls, Rochester, Scotland, Israel, and Latvia. These regions are followed by Switzerland, New York-Northern New Jersey-Long Island, Seattle-Tacoma-Bellevue, Westösterreich (Australia), and Emilia-Romagna, which have all shown a marginal increase in expenditure.

Growth in private equity investment shows a significant contrast between Chinese regions and US regions. It is clear that the biggest growth has occurred in Chinese regions, which occupy the top 7 spots in the rankings, followed by Taiwan, New South Wales, and Victoria in Australia. In the US, the traditional heartland of venture capital, most regions have seen a fall in levels of such capital investment. Of the all regions analyzed, 30 regions have shown a double-digit decline in percentage terms, with only two regions (Latvia and Bratislavsky) being outside the US. Those US regions, which have seen the largest falls, include HartfordWest Hartford-East Hartford, Louisville, Orlando-Kissimmee, Jacksonville, TampaSt. Petersburg-Clearwater, Miami-Fort Lauderdale-Miami Beach, Memphis, Phoenix-MesaScottsdale, Milwaukee-Waukesha-West Allis, and Las Vegas-Paradise.

Finally, for the three ICT infrastructure indicators, Chinese regions have made the greatest strides in ICT development. In particular, the Chinese regions have achieved a three-digit growth in percentage terms in Internet hosts per capita and secure servers per capita, resulting in them dominating the top 10 rankings. Bratislavsky, Praha, and Lithuania follow them in the growth of Internet hosts, and Bratislavsky, Praha, and Taiwan in the growth of secure servers. European, Australian, and Japanese regions have shown modest growth in both Internet hosts and secure servers, occupying middle positions in the rankings. In contrast, US and Canadian regions lag behind in the pace of their development. The bottom 10 regions include two Canadian regions (Manitoba and Saskatchewan) and eight US regions (San Antonio, Buffalo-Niagara Falls, Tampa-St. Petersburg-Clearwater, Grand Rapids-Wyoming, Rochester, Detroit-Warren-Livonia, Jacksonville, and Louisville).

The Chinese regions lead the growth of broadband access, although their rates of growth are more comparable with those shown by European and Australian regions. The top 10 spots are populated by Chinese and European (mostly East European) regions, including Beijing, Shanghai, Guangdong, and Zhejing in China, and Bratislavsky, Praha, Southern and Eastern (Ireland), Közép-Magyarország, and Lithuania in Europe, as well as Ontario. In Europe, Swedish regions are anomalies to this trend, with Småland med Öarna, Sydsverige, and Västsverige occupying three of the bottom 10 spots possibly due to the existing high levels of access already available in these regions. In addition, Japanese and Canadian regions have shown weak growth in the diffusion of broadband access. Aside from the three Swedish regions, Manitoba, Saskatchewan, Kanagawa, and Kyoto enter the list of the bottom 10 regions. Taiwan, Israel, and Singapore are also in the bottom 10 list.

\section{Discussion}

This section discusses the key results of the study based on both a factor analysis and cluster analysis of the overarching findings.

\subsection{Waves of growth: factor analysis}

Utilizing the results of the factor analysis, the original variables are reduced to three factors, each of which represents a unique combination of the original variables. The three identified factors explain 64.50 per cent of the total variance, a satisfactory level given the 
fact that more than 100 regions are included, with the subsequent analysis focusing on those variables with a loading greater than \pm 0.40 (Gorsuch, 1983).

\section{[INSERT TABLE 2]}

As shown by Table 2, Factor 1 indicates a close association between the growth of hightech services employment, Internet hosts, venture capital, patent registration, and public expenditures on higher education. Growth in economic activity rates and falls in mean gross monthly earnings rates are also significantly loaded on this factor. This factor is labeled 'Fifth Wave Growth' as it indicates a close association between ICT-based service growth, growth in knowledge outputs, and growth in key knowledge-based investments.

The close association identified between employment in high-tech services and Internet hosts, as well as private equity investment capital, signifies the newest fifth wave of economic development. Furthermore, the factor's association with patents, which is found to grow during the upswing of a long wave (Korotayev et al., 2011), further strengthens its representation as a fifth wave. Of course, our analysis cannot be said to infer causality, but at an exploratory level it does suggest that across this cohort of leading regions in both established and emerging economies the trajectory of knowledge-based service sectors and patents generally moves in the same direction as growth in venture capital, as well as investment in ICT infrastructure and higher education, chiming with the propositions of innovation systems theory.

The second factor mainly represents employment growth in the four knowledge-intensive manufacturing sectors and growth in patent registrations, with growth in Internet hosts and economic activity rates also marginally loaded. We label this factor 'Third \& Fourth Wave Growth', as those manufacturing sectors represent leading industries in the third and fourth waves. As for the third factor, highly loaded variables include growth in R\&D expenditures performed by business and employment in automotive and mechanical engineering, as well as instrumentation and electrical machinery. Growth in employment rates (namely, a decline in the unemployment rate) is also significantly loaded on this factor. We call this factor 'Government-led Third Wave Growth', suggesting a close association between public R\&D spending growth and growth in third wave manufacturing sectors. The loading of employment rate growth may also be interpreted as a sign of an interventionist approach taken by government in job creation and its association with the older generation of knowledge-intensive manufacturing sectors.

\subsection{Waves of growth: cluster analysis}

Following the factor analysis, cluster analysis is undertaken to identify groups of regions. Regions within a group are close to one another according to the distance defined by their factor scores. Figures 2 and 3 show the identified 13 groups of regions in three-dimensional space consisting of the three factors. Chinese regions are clearly set apart from the rest of the regions in terms of their extremely high values for Fifth Wave Growth. Furthermore, the Chinese regions show much wider variations in their values for the Third \& Fourth Wave Growth than the rest of the regions. As a result, each of the seven Chinese regions forms a cluster of its own.

By construct, the Fifth Wave Growth and the Third \& Fourth Wave Growth are necessarily orthogonal, with their values showing no correlation. However, in Figure 2, the Chinese regions show a pattern of negative association between the Fifth Wave Growth and Third \& Fourth Wave Growth. In a similar vein, the negative association is replicated among the rest of the regions as well, meaning that those regions showing faster growth in high-tech 
services employment, venture capital, and public expenditures on higher education tend to exhibit slower growth, or even falls, in employment in the four knowledge-intensive manufacturing industries.

In the close-up section of Figure 2, which focuses on the distribution of non-Chinese regions, a few clusters are identified at the opposite corners, with a three-region cluster of New South Wales, Victoria, and Taiwan and a single-region cluster of Nashville-DavidsonMurfreesboro in the right-hand bottom, and a two-region cluster of Estonia and Latvia in the left-hand top. As for the rest of the non-Chinese regions, although there is a significant overlap, US regions tend to be situated in the bottom right-hand quadrant, whilst European regions are in the top left-hand area, with Japanese regions occupying the middle ground.

The US and European regions are clearly separated in terms of the Government-led Third Wave Growth, as shown by Figure 3. All US regions, except for Nashville-DavidsonMurfreesboro and Salt Lake City, form a cluster situated at the bottom, along with Saskatchewan (Canada) and Kanagawa (Japan). There is an independent cluster of three Swedish regions (Småland med Öarna, Västsverige, and Sydsverige) situated at the top, with the rest of the regions forming another large cluster, consisting mainly of European, Japanese, and Canadian regions. Clearly, the two large clusters are differentiated in terms of Government-led Third Wave Growth, with the European cluster showing faster growth than the US cluster.

\section{[INSERT FIGURES $2 \& 3$ ]}

Four key findings emerge from the results. First, there is a spread of knowledge-based resources in the form of human capital formation, knowledge production, and entrepreneurial investment, as well as overall economic growth in GDP and labor productivity, in regional economies within China. In the three key growth trends identified, the Chinese regions stand out from the rest in Fifth Wave and Third \& Fourth Wave Growth. In terms of the Fifth Wave Growth, all the seven Chinese regions grew at a faster pace than the rest of the regions analyzed.

Among the more established regions, many of those showing relatively strong performance in terms of Fifth Wave Growth are located around the Pacific Rim, such as Victoria, New South Wales, Taiwan, Washington, British Columbia, and New Zealand, indicating that they enjoy an opportunity for the offshoring of labor-intensive operations to China, as well as robust demand from within the Chinese economy. As for the Third \& Fourth Wave Growth, again, four of the seven Chinese regions (Jiangsu, Shandong, Zhejing, and Guangdong) grew faster than all the non-Chinese regions. Across the non-Chinese regions, those showing strong performance are to a large extent concentrated in Eastern Europe, including Estonia, Latvia, Bratislavsky, Praha, Lithuania, and Közép-Magyarország. Overall, a continued shift of knowledge-based resources and capabilities to the East can be observed, or what can be termed the globalization of knowledge-based development.

Second, a bipolar development can be observed with regard to Fifth Wave Growth on the one hand andThird \& Fourth Wave Growth on the other. As mentioned earlier, by construct of factor analysis, the Fifth Wave Growth and the Third \& Fourth Wave Growth are orthogonal, with their values showing no association at all. This means that, at the global scale, a region's position on the Fifth Wave Growth shows no indication of its position on the Third \& Fourth Wave growth, and vice versa. However, as shown in Figure 2, when the Chinese regions and the non-Chinese regions are divided into two separate groups, we observe in each of the groups a close negative association between the values for both Fifth Wave Growth and Third \& Fourth Wave Growth, meaning that a region with faster growth in 
high-tech service employment and venture capital formation tends to show a slower growth (or a faster fall) in knowledge-intensive manufacturing employment, and vice versa. Whilst the speed at which this development has taken place is much faster within the Chinese regions, what is common between the two groups of regions is a growing sector specialization in either high-tech services accompanied by venture capital formation, or knowledge-intensive manufacturing.

Third, sector specialization emerges as one of the three key trends by which the economic evolution and growth patterns of leading regions across the globe are differentiated. In addition to the first two factors, the third factor concerns employment change in the Third Wave manufacturing industries, automotive and mechanical engineering, as well as instrumentation and electrical machinery. Within this Government-led Third Wave Growth, two large clusters - the US-centric cluster and the Europe-centric cluster-are identified, along with a few much smaller clusters at the fringe.

Fundamentally, the superstructure identified by the analysis is based on sector specialization, and is in contrast to an observation from an earlier period at the turn of the new century. In an earlier study of the period from 2001/02 to 2004/05 (Huggins and Izushi, 2013), it is found that the key trends differentiating the globe's most productive regions are not sector employment change but a commonality among the growth of GDP, gross monthly earnings, and business $\mathrm{R} \& \mathrm{D}$, as well as labor market growth. This change in the identified factors may indicate that leading regions have been in the process of repositioning themselves in the global value chain through sector specialization in response to the major shocks, including the bursting of the dotcom bubble in 2001 and the economic crisis that emerged in 2007.

Last, but not least, the factor analysis presented above does not indicate the insignificance of labor productivity growth as an indicator of knowledge-based growth. In Table 2, labor productivity is conspicuously not loaded on any of the three factors strongly. However, this means that labor productivity growth is not associated with any one of the three diverging waves alone, but it is to a great extent evenly associated with all waves. Technical progress appears to have taken place within each of the sectors associated with the three factors, and by design the factor analysis identifies commonalities orthogonal to, or independent of, each other, resulting in labor productivity not being strongly loaded on any of the factors. In a similar vein, the growth of private R\&D expenditure is not loaded strongly on any of the three factors, although an analysis regressing labor productivity growth shows that it is closely associated with the growth of private $R \& D$ expenditure.

\section{Conclusion}

It is widely observed that the global geography of innovation is rapidly evolving. This paper presents evidence concerning the contemporary evolution of the globe's most productive regions, uncovering the underlying structure and coevolution of knowledge-based resources, capabilities and outputs across these regions. To this end, it provides useful pointers to the schools of knowledge-based urban development and knowledge city/research in understanding the links between the growth of knowledge-based inputs and resources, and accompanying capabilities and outputs. Importantly, it develops an understanding of how these links are evolving in a differing ways across regions and cities, which to some extent is dependent on geospatial positioning. Clearly, a route for further research in the area of knowledge-based urban development would be to seek to integrate changing patterns of 
societal and environmental development - especially the role of underlying institutions - with these broadly evolving patterns of economic competitiveness, innovation and growth.

Overall, the analysis identifies three key trends by which the economic evolution and growth patterns of these regions are differentiated - namely Fifth Wave Growth, Third \& Fourth Wave Growth, and Government-led Third Wave Growth. Overall, spectacular knowledge-based growth of leading Chinese regions is evident, highlighting a continued shift of knowledge-based resources to Asia. In addition, a superstructure is observed at the global scale, consisting of two separate continuums that explicitly distinguish Chinese regions from the rest in terms of regional growth trajectories. However, as other research has found, it should not be assumed that the growth models existing across Chinese regions are based on a generic recipe, but often on quite differing drivers, policies, and institutions (Huggins et al., 2013).

In the case of European regions, the changing patterns of global trade and development has made the resilience of competitiveness in European regions a core concern of the European Union and the governments of constituent nation states, as well as aspiring members (Reiner, 2010; Koschatzky and Stahlecker, 2010). Concerns about the loss of regional competitiveness have moved further up the agenda of European governments with the onset of the financial crisis in 2007 and the recession that followed (European Commission, 2010). Structural problems and the direct exposure of banking systems to the US sub-prime mortgage market have resulted in European economies not only suffering deeper and longer recessions than other national economies, but also weaker recoveries (Claessens et al., 2010; Yurtsever, 2011). Competitiveness disparities within European nations mean that the capability to withstand and overcome shocks is likely to vary across European regions.

In North America, the US faces an on-going erosion of its competitiveness on the international stage, with it continuing to slip down national competitiveness rankings, a fall which has undoubtedly been accentuated by the 2007 financial crisis (World Economic Forum, 2012; IMD, 2013). In Asia-Pacific, regional growth in Australia is found to be a complex interaction between population growth, human capital and economic structure (Stimson et al., 2009), whilst in Japan regional competitiveness and growth has been related to a pattern of rising overseas investment coupled with the increased import penetration of less technology-intensive products to Japan (Essletzbichler and Kadokawa, 2010).

\section{References}

Acs, Z.J., Anselin, L., and Varga, A. (2002) Patents and innovation counts as measures of regional production of new knowledge, Research Policy, 31(7), pp. 1069-1085.

Adams, J.D. (1990) Fundamental stocks of knowledge and productivity growth, Journal of Political Economy, 98(4), pp. 673-702.

Bartholomew, D.J. and Knott, M. (1999) Latent Variable Models and Factor Analysis, 2nd ed. London: Arnold.

Begg, I. (1999) Cities and competitiveness, Urban Studies, 36(5/6), pp. 795-810.

Bilbao-Osorio, B. and Rodríguez-Pose, A. (2004) From R\&D to innovation and economic growth in the EU, Growth and Change, 35(4), pp. 434-455.

Borrás, S. (2004) System of innovation theory and the European Union, Science and Public Policy, 31(6), pp. 425-433.

Boschma, R. (2004). Competitiveness of regions from an evolutionary perspective, Regional Studies, 38(9), pp. 1001-1014. 
Bradley, S. and Taylor, J. (1996) Human capital formation and local economic performance, Regional Studies, 30(1), pp. 1-14.

Buerger, M., Broekel, T., and Coad, A. (2010) Regional dynamics of innovation: investigating the co-evolution of patents, research and development (R\&D), and employment, Regional Studies, DOI:10.1080/00343404.2010.520693.

Buesa, M., Heijs, J., Pellitero, M.M., and Baumert, T. (2006) Regional systems of innovation and the knowledge production function: the Spanish case, Technovation, 26(4), p. 463-472.

Buesa, M., Heijs, J., and Baumert, T. (2010) The determinants of regional innovation in Europe: A combined factorial and regression knowledge production function approach, Research Policy, 39(6), pp. 722-735.

Carlsson, B. (2003) Innovation systems: a survey of the literature from a Schumpeterian perspective. Paper for the Elgar Companion to Neo-Schumpeterian Economics, June.

Camagni, R. and Capello, R. (2012). Regional competitiveness and territorial capital: a conceptual approach and empirical evidence from the European Union, Regional Studies, DOI:10.1080/00343404.2012.681640.

Carrillo, F (2004) Capital cities: a taxonomy of capital accounts for knowledge cities. Journal of Knowledge Management 8(5), pp. 28-46.

Carrillo, F. (2006) The century of knowledge cities, in Carrillo, F. (Ed.), Knowledge Cities: Approaches, Experiences, and Perspectives, Butterworth-Heinemann, New York, NY, pp. xi-xv.

Claessens, S., Dell'Ariccia, G., Igan, D. and Laeven, L. (2010). Cross-country experiences and policy implications from the global financial crisis, Economic Policy, 25(62), pp. 267-293.

Cooke, P. (2004) Regional innovation systems: an evolutionary approach, in: P. Cooke, M. Heidenreich, and H.-J. Braczyk (Eds.) Regional Innovation Systems, 2nd ed. pp. 1-18. London: Routledge.

Crescenzi, R., Rodríguez-Pose, A., and Storper. M. (2007) The territorial dynamics of innovation: a Europe-United States comparative analysis, Journal of Economic Geography, 7(6), pp. 673-709.

Crouch, C., Finegold, D., and Sako, M. (1999) Are Skills the Answer? Oxford: Oxford University Press.

Devezas, T.C., Linstone, H.A., Santos, H.J.S. (2005) The growth dynamics of the Internet and the long wave theory, Technological Forecasting \& Social Change, 72(8), pp. 913-935.

Doloreux, D. and Parto, S. (2005) Regional innovation systems: current discourse and unresolved issues, Technology in Society, 27(2), pp. 133-153.

Döpke, J. (2001) The "employment intensity" of growth in Europe, Kiel Working Paper No. 1021, Kiel Institute of World Economics, Kiel Germany).

Dunford, M. (2005) Old Europe, new Europe and the USA: Comparative economic performance, Inequality and market-led models of development, European Urban and Regional Studies, 12(2), pp. 149-176.

Essletzbichler, J. and Kadokawa, K. (2010) The evolution of regional labour productivities in Japanese manufacturing, 1968-2004, Regional Studies, 44(9), pp. 1189-1205.

European Commission (2010). Europe 2020: A Strategy for Smart, Sustainable and Inclusive Growth, Brussels: European Commission.

Fagerberg, J. (1996) Technology and competitiveness, Oxford Review of Economic Policy, 12(3), pp. 39-51.

Freeman, C. (2002) Continental, national and sub-national innovation systems complementarity and economic growth, Research Policy, 31(2), pp. 191-211. 
Fritsch, M. (2002) Measuring the quality of regional innovation systems: a knowledge production function approach, International Regional Science Review, 25(1), pp. 86101.

Gorsuch, R.L. (1983) Factor Analysis, 2nd ed. Hills Dale, NJ: Lawrence Erlbaum Associates. Griliches, Z. (1990) Patent statistics as economic indicators: a survey, Journal of Economic Literature, 28(4), pp. 1661-1707.

Hair, Jr., J.F., Black, W.C., Babin, B.J., and Anderson, R.E. (2010) Multivariate Data Analysis, 7th ed., Upper Saddle River, NJ: Pearson.

Hatzichronoglou, T. (1997) Revision of the high-technology sector and product classification. STI Working Papers, 2, Paris: OECD.

Heidenreich, M. (2004) The dilemmas of regional innovation systems, in: P. Cooke, M. Heidenreich, and H.-J. Braczyk (Eds.) Regional Innovation Systems, 2nd ed. pp. 363389. London: Routledge.

Huggins, R. (2003) Creating a UK competitiveness index: regional and local benchmarking, Regional Studies, 37(1), pp. 89-96.

Huggins, R. (2010). Regional competitive intelligence: benchmarking and policy-making, Regional Studies, 44(5), pp. 639-658.

Huggins, R. and Izushi, H. (2007) Competing for Knowledge: Creating, Connecting, and Growing, London: Routledge.

Huggins, R. and Thompson, P. (2013) A network-based view of regional growth, Journal of Economic Geography, doi:10.1093/jeg/lbt012.

Huggins, R. and Izushi, H. (2013) Knowledge-based development in leading regions across the globe: An exploratory analysis of the co-evolution of resources, capabilities and outputs, Urban Studies, 50(5), pp. 1030-1048.

Huggins, R., Luo, S. and Thompson, P. (2013) The competitiveness of China's leading regions: benchmarking their knowledge-based economies, Tijdschrift voor Economische en Sociale Geografie, doi:10.1111/tesg.12065

Iammarino, S. and McCann, P. (2006) The structure and evolution of industrial clusters: transactions, technology and knowledge spillovers, Research Policy, 35(7), pp. 1018 1036.

IMD (2013) The World Competitiveness Yearbook, Lausanne, Switzerland: IMD World Competitiveness Center.

Jaffe, A.B. (1989) Real effect of academic research, American Economic Review, 79(5), pp. 957-970.

Kitson, M., Martin, R. and Tyler, P. (2004). Regional competitiveness: An elusive yet key concept? Regional Studies, 38, pp. 991-999.

Knight, R (1995) Knowledge-based development: policy and planning implications for cities. Urban Studies 32(2), pp. 225-260.

Knight, R. (2008) Knowledge-based development, in Yigitcanlar, T., Velibeyoglu, K. and Baum, S. (Eds), Knowledge-based Urban Development, Information Science Reference, London, pp. xiii-xxv.

Kline, S.J. and Rosenberg, N. (1986) An overview of innovation, in: R. Landau and N. Rosenberg (Eds.) The Positive Sum Strategy, pp. 275-305. Washington, DC: National Academy Press.

Kondratieff, N.D. (1926) 'Die langen Wellen der konjunktur', Archiv für Sozialwissenschaft, $56,573-609$.

Kondratieff, N.D. (1935) 'The long waves in economic life', Review of Economic Statistics, $17(6), 105-115$. 
Korotayev, A., Zinkina, J., and Bogevolnov, J. (2011) Kondratieff waves in global invention activity (1900-2008), Technological Forecasting \& Social Change, 78(7), pp. 12801284

Koschatzky, K. and Stahlecker, T. (2010) A new challenge for regional policy-making in Europe? Chances and risks of the merger between cohesion and innovation policy, European Planning Studies, 18(1), pp. 7-25.

Kunzmann, K. (2008) Spatial dimensions of knowledge production. In T. Yigitcanlar, K. Velibeyoglu, \& S. Baum (Eds.) Knowledge-Based Urban Development (pp. 296-300). Hersey, PA: IGI-Global.

Kunzmann, K. (2009) The Strategic Dimensions of Knowledge Industries in Urban Development. (Zurich: Network, City and Landscape DISP-Online).

Laafia, I. (1999) Regional employment in high technology, Statistics in Focus, Research and Development Theme, 9(1). Luxembourg: Eurostat.

Lee, F.C. and Has, H. (1996) A quantitative assessment of high-knowledge industries versus low-knowledge industries, in: P. Howitt (Ed.) The Implications of Knowledge-Based Growth for Micro-Economic Policies, pp. 39-78. Calgary: University of Calgary Press.

Linstone, H.A. and Devezas, T. (2012) Technological innovation and the long wave theory revisited, Technological Forecasting \& Social Change, 79(2), pp. 414-416.

Lönnqvist, A., Käpylä, J., Salonius, H. And Yigitcanlar, T. (2013) Knowledge that matters: identifying regional knowledge assets of the Tampere Region, European Planning Studies, doi: 10.1080/09654313.2013.814621.

Malecki, E. J. (2004) Jockeying for position: what it means and why it matters to regional development policy when places compete, Regional Studies, 38(9), pp. 1101-1120.

Malecki, E. J. (2007) Cities and regions competing in the global economy: knowledge and local development policies, Environment and Planning C: Government and Policy, 25(3), pp. 638-654.

Markusen, A. (1996) Sticky places in slippery spaces: a typology of industrial districts, Economic Geography, 72(3), pp. 293-313.

OECD (1994) Jobs Study: Evidence and Explanations. Paris: OECD.

Ovalle, M., Marquez, J. and Salomon, S. (2004) A compilation on knowledge cities and knowledge-based development, Journal of Knowledge Management, 8(5), pp. 107-127.

Pavitt, K. (1982) R\&D, patenting and innovative activities: a statistical exploration, Research Policy, 11(1), pp. 33-51.

Phelps, N.A. and Ozawa, T. (2003) Contrasts in agglomeration: proto-industrial, industrial and post-industrial forms compared, Progress in Human Geography, 27(5), pp. 583604.

Reiner, C. (2010). Brain competition policy as a new paradigm of regional policy: a European perspective, Papers in Regional Science, 89(2), pp. 449-461.

Rodríguez-Pose, A. and Crescenzi, R. (2008) Research and development, spillovers, innovation systems, and the genesis of regional growth in Europe, Regional Studies, 42(1), pp. 51-67.

Schumpeter, J.A. (1939) Business Cycles, New York: McGraw-Hill.

Schwarz, G. (1978) Estimating the dimension of a model, Annals of Statistics, 6(2), pp. 461464.

Stimson, R. J., Robson, A. and Shyy, T.-K. (2009) Modeling regional endogenous growth: an application to the non-metropolitan regions of Australia, Annals of Regional Science, 43(2), pp. 379-398.

Vivarelli. M and Pianta, M. (eds.) (2000) The Employment Impact of Innovation: Evidence and Policy, London: Routledge. 
World Economic Forum (2012) Global Competitiveness Report, 2012-2013, Geneva, Switzerland: World Economic Forum.

Wymbs, C. (2004) Telecommunications, and instrument of radical change for both the 20th and 21 st centuries, Technological Forecasting \& Social Change, 71(7), pp. 685-703.

Yigitcanlar, T. (2009) Planning for knowledge-based urban development: global perspectives, Journal of Knowledge Management, 13(5), pp. 228-242.

Yigitcanlar, T. (2010) Making space and place for the knowledge economy, European Planning Studies, 18(11), pp. 1769-1786.

Yigitcanlar, T. and Lönnqvist, A. (2013) Benchmarking knowledge-based urban development performance, Cities, 31, pp. 357-369.

Yigitcanlar, T., O'Connor, K. And Westerman, C. (2008) The making of knowledge cities: Melbourne's knowledge-based urban development experience, Cities, 25, pp. 63-72.

Yurtsever, S (2011). Investigating the recovery strategies of European Union from the global financial crisis, Procedia Social and Behavioral Sciences, 24, 687-695. 


\section{Appendix 1}

Regions Analyzed.

North America

Atlanta-Sandy Springs-Marietta, US

Austin-Round Rock, US

Baltimore-Towson, US

Boston-Cambridge-Quincy, US

Buffalo-Niagara Falls, US

Charlotte-Gastonia-Concord, US

Chicago-Naperville-Joliet, US

Cincinnati-Middletown, US

Cleveland-Elyria-Mentor, US

Columbus, US

Dallas-Fort Worth-Arlington, US

Denver-Aurora, US

Detroit-Warren-Livonia, US

Grand Rapids-Wyoming, US

Greensboro-High Point, US

Hartford-West Hartford-East Hartford, US

Houston-Sugar Land-Baytown, US

Indianapolis, US

Jacksonville, US

Kansas City, US

Las Vegas-Paradise, US

Los Angeles-Long Beach-Santa Ana, US

Louisville, US

Memphis, US

Miami-Fort Lauderdale-Miami Beach, US

Milwaukee-Waukesha-West Allis, US

Minneapolis-St. Paul-Bloomington, US

Nashville-Davidson--Murfreesboro, US

New York-Northern New Jersey-Long

Island, US

Orlando-Kissimmee, US

Philadelphia-Camden-Wilmington, US

Phoenix-Mesa-Scottsdale, US

Pittsburgh, US

\section{Europe}

Région de Bruxelles-Capitale, Belgium

Vlaams Gewest, Belgium

Baden-Württemberg, Germany

Bayern, Germany

Berlin, Germany

Hessen, Germany

Niedersachsen, Germany

Nordrhein-Westfalen, Germany

Saarland, Germany

Schleswig-Holstein, Germany

Estonia

Noreste, Spain

Comunidad de Madrid, Spain

Île de France, France

Centre-Est, France

Southern and Eastern, Ireland

Emilia-Romagna, Italy

Lazio, Italy

Lombardia, Italy

Latvia

Lithuania

Noord-Nederland, Netherlands

West-Nederland, Netherlands

Zuid-Nederland, Netherlands

Ostösterreich, Austria

Westösterreich, Austria

Etelä-Suomi, Finland

Småland med Öarna, Sweden

Stockholm, Sweden

Sydsverige, Sweden

Västsverige, Sweden

Eastern, UK

London, UK

\section{Asia and Oceania}

New South Wales, Australia

Victoria, Australia

Western, Australia

Aichi, Japan

Kanagawa, Japan

Kyoto, Japan

Osaka, Japan

Shiga, Japan

Shizuoka, Japan

Tochigi, Japan

Tokyo, Japan

Toyama, Japan

New Zealand

Singapore

Taiwan

Shanghai, China

Beijing, China

Tianjin, China

Guangdong, China

Jiangsu, China

Zhejing, China

Shandong, China 
Paper\#03

Portland-Vancouver-Beaverton, US

Raleigh-Cary, US

Richmond, US

Rochester, US

Sacramento--Arden-Arcade--Roseville, US

Salt Lake City, US

San Antonio, US

San Diego-Carlsbad-San Marcos, US

San Francisco-Oakland-Fremont, US

San Jose-Sunnyvale-Santa Clara, US

Seattle-Tacoma-Bellevue, US

St. Louis, US

Tampa-St. Petersburg-Clearwater, US

Virginia Beach-Norfolk-Newport News, US

Washington-Arlington-Alexandria, US

Alberta, Canada

British Columbia, Canada

Manitoba, Canada

Ontario, Canada

Quebec, Canada

Saskatchewan, Canada
Scotland, UK

South East, UK

Norway

Switzerland

Bratislavsky, Slovak Republic

Közép-Magyarország, Hungary

Praha, Czech Republic

Israel 
Fig 1. Analytical Framework and Variables Employed.

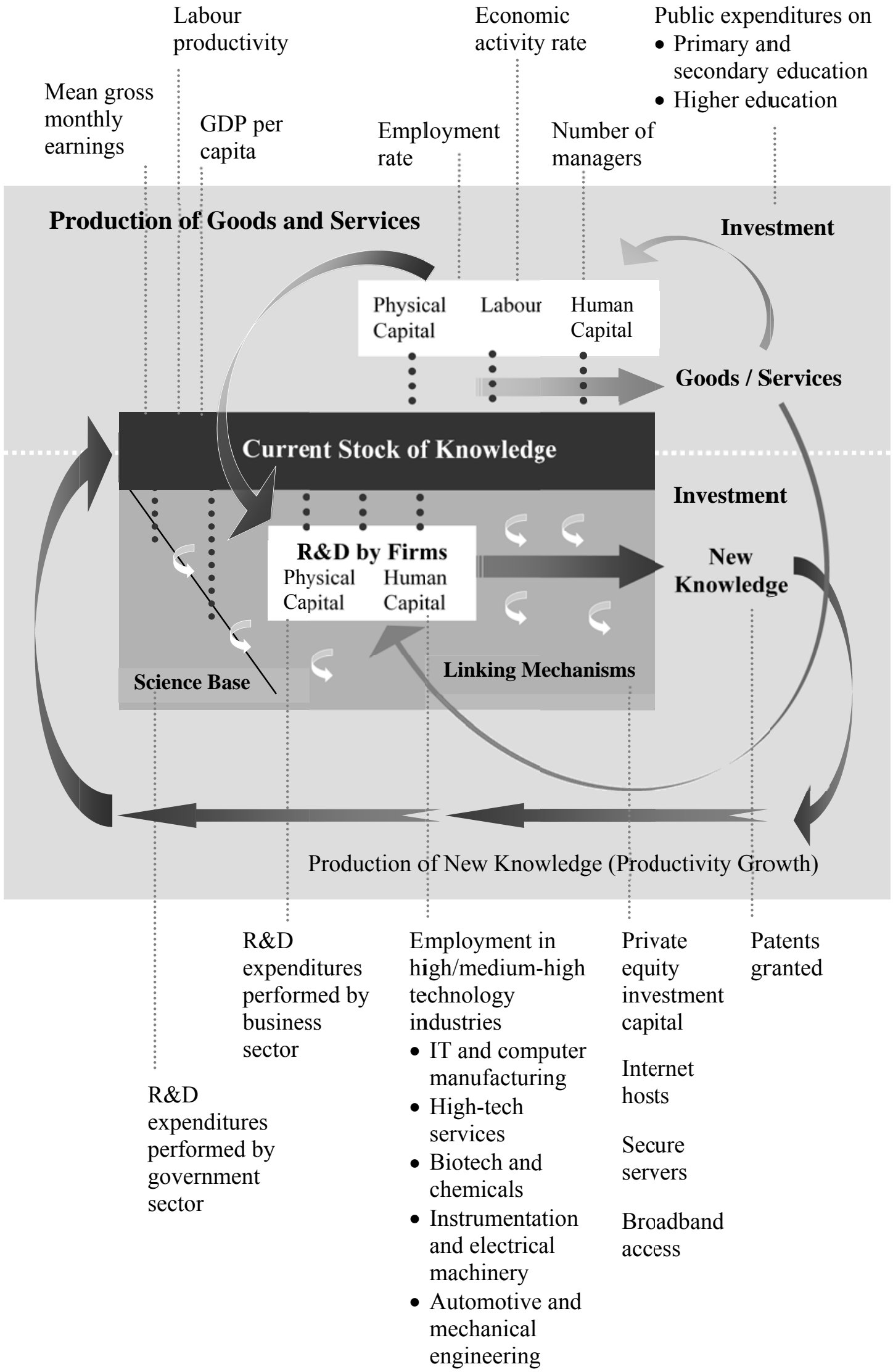


Fig 2. Regions and Third \& Fourth and Fifth Waves Growth of Growth.
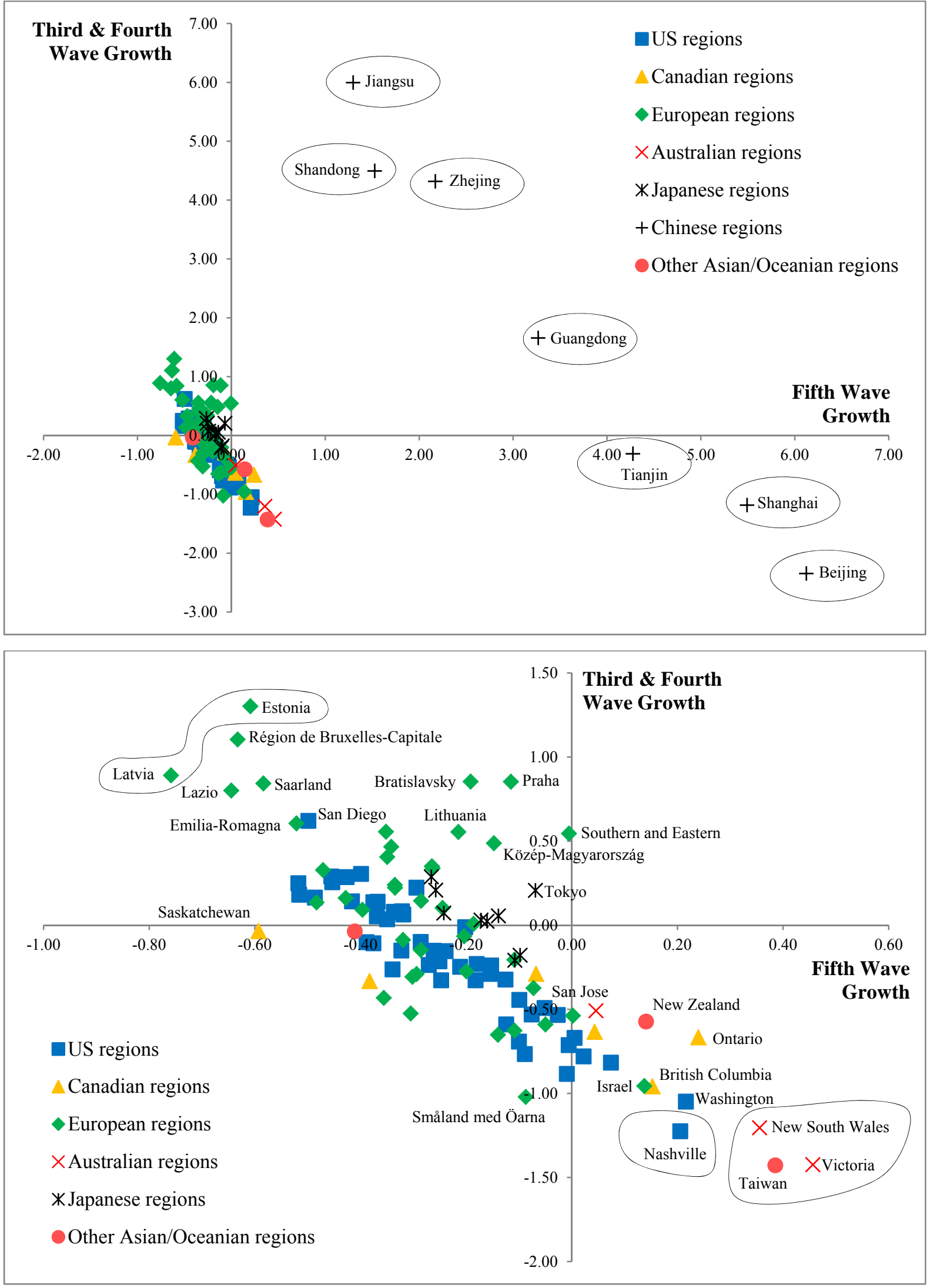
Fig 3. Fifth Wave Growth and Government-led Third Wave Growth.

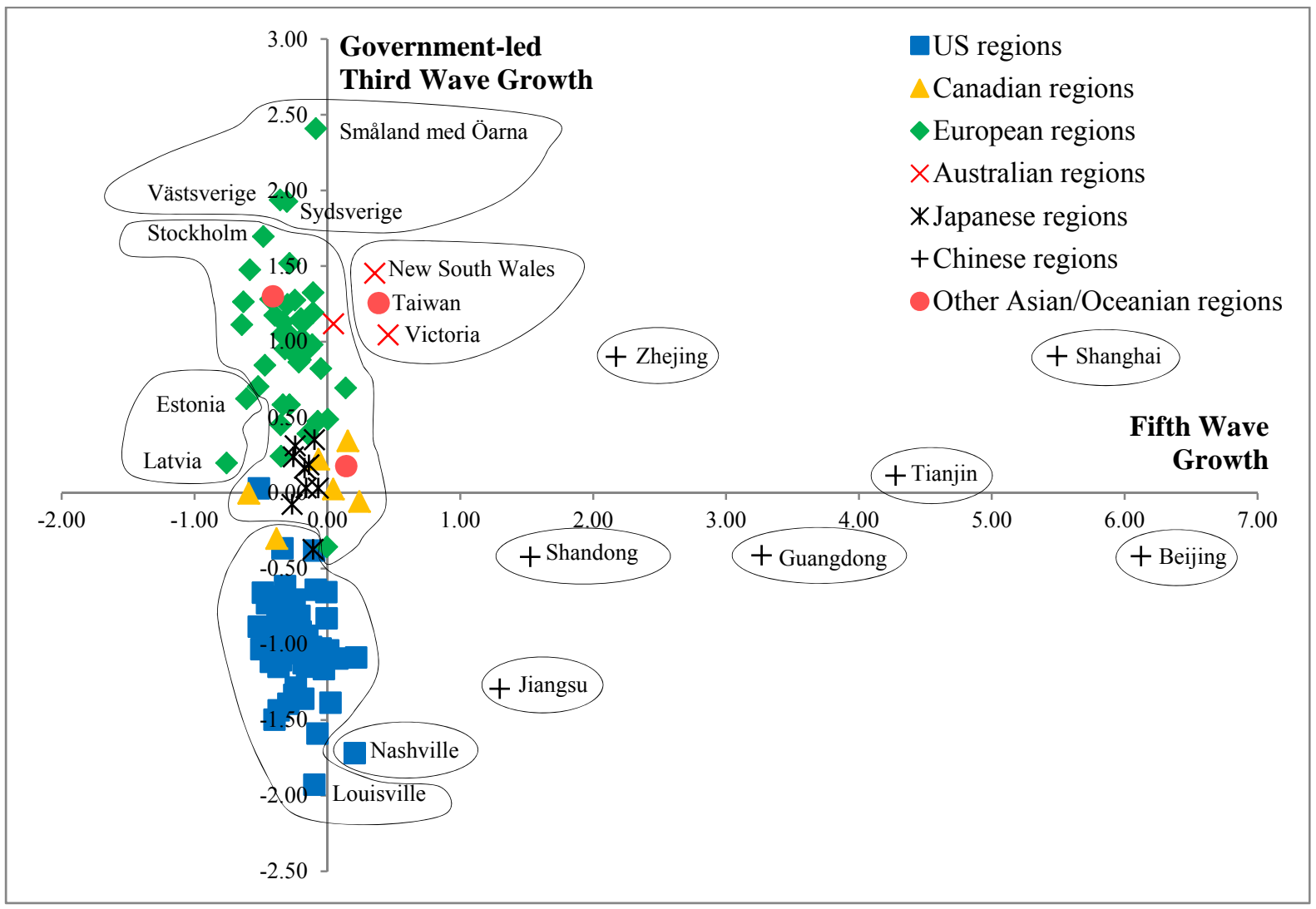

Cluster 1: Beijing

Cluster 2: Shanghai

Cluster 3: Tianjin

Cluster 4: Guangdong

Cluster 5: Zhejing

Cluster 6: Shanghai

Cluster 7: Shandong

Cluster 8: New South Wales, Victoria (Australia), Taiwan

Cluster 9: Nashville-Davidson-Murfreesboro (US)

Cluster 10: Atlanta-Sandy Springs-Marietta, Austin-Round Rock, Baltimore-Towson, Boston-CambridgeQuincy, Buffalo-Niagara Falls, Charlotte-Gastonia-Concord, Chicago-Naperville-Joliet, CincinnatiMiddletown, Cleveland-Elyria-Mentor, Columbus, Dallas-Fort Worth-Arlington, Denver-Aurora, Detroit-Warren-Livonia, Grand Rapids-Wyoming, Greensboro-High Point, Hartford-West Hartford-East Hartford, Houston-Sugar Land-Baytown, Indianapolis, Jacksonville, Kansas City, Las Vegas-Paradise, Los Angeles-Long Beach-Santa Ana, Louisville, Memphis, Miami-Fort Lauderdale-Miami Beach, Milwaukee-Waukesha-West Allis, Minneapolis-St. Paul-Bloomington, New York-Northern New Jersey-Long Island, Orlando-Kissimmee, Philadelphia-CamdenWilmington, Phoenix-Mesa-Scottsdale, Pittsburgh, Portland-Vancouver-Beaverton, Raleigh-Cary, Richmond, Rochester, Sacramento-Arden-Arcade - Roseville, San Antonio, San Diego-CarlsbadSan Marcos, San Francisco-Oakland-Fremont, San Jose-Sunnyvale-Santa Clara, Seattle-TacomaBellevue, St. Louis, Tampa-St. Petersburg-Clearwater, Virginia Beach-Norfolk-Newport News, Washington-Arlington-Alexandria (US), Saskatchewan (Canada), Kanagawa (Japan)

Cluster 11: Salt Lake City (US), Alberta, British Columbia, Manitoba, Ontario, Quebec (Canada), Région de Bruxelles-Capitale, Vlaams Gewest (Belgium), Baden-Württemberg, Bayern, Berlin, Hessen, Niedersachsen, Nordrhein-Westfalen, Saarland, Schleswig-Holstein (Germany), Noreste, Comunidad de Madrid (Spain), Île de France, Centre-Est (France), Southern and Eastern (Ireland), 
Paper\#03

Emilia-Romagna, Lazio, Lombardia (Italy), Noord-Nederland, West-Nederland, Zuid-Nederland (Netherlands), Ostösterreich, Westösterreich (Austria), Etelä-Suomi (Finland), Stockholm (Sweden), Eastern, London, Scotland, South East (UK), Bratislavsky (Slovak Republic), Közép-Magyarország (Hungary), Praha (Czech Republic), Lithuania, Norway, Switzerland, Israel, Western (Australia), Aichi, Kyoto, Osaka, Shiga, Shizuoka, Tochigi, Tokyo, Toyama (Japan), New Zealand, Singapore

Cluster 12: Sydsverige, Västsverige, Småland med Öarna (Sweden)

Cluster 13: Estonia, Latvia 
Table 1

Average compound annual growth rates of 20 variables from 2000/01 to 2010/11 or equivalent (percentage).

\begin{tabular}{|c|c|c|c|c|c|c|c|}
\hline & $\begin{array}{l}\text { US } \\
\text { regions }\end{array}$ & $\begin{array}{l}\text { Canadia } \\
\mathrm{n} \\
\text { regions }\end{array}$ & $\begin{array}{l}\text { Europea } \\
\mathrm{n} \\
\text { regions }\end{array}$ & $\begin{array}{l}\text { Australi } \\
\text { an } \\
\text { regions }\end{array}$ & $\begin{array}{l}\text { Japanese } \\
\text { regions }\end{array}$ & $\begin{array}{l}\text { Chinese } \\
\text { regions }\end{array}$ & $\begin{array}{l}\text { All } \\
\text { region } \\
\mathrm{s}\end{array}$ \\
\hline $\begin{array}{l}\text { Gross domestic product per } \\
\text { inhabitant }\end{array}$ & 3.64 & 4.18 & 4.15 & 4.35 & 3.66 & 7.60 & 4.18 \\
\hline Labor productivity & 2.39 & 2.63 & 3.46 & 3.07 & 1.88 & 4.89 & 2.95 \\
\hline $\begin{array}{l}\text { Mean gross monthly } \\
\text { earnings }\end{array}$ & 7.20 & 4.68 & 5.53 & 1.62 & 6.97 & -2.40 & 5.67 \\
\hline Economic activity rate & 0.99 & -0.04 & 0.21 & 0.42 & 1.92 & 10.09 & 1.25 \\
\hline Employment rate & -0.50 & 0.04 & -0.15 & 0.14 & 0.07 & 0.06 & -0.24 \\
\hline $\begin{array}{l}\text { Number of managers per } \\
1,000 \text { employees }\end{array}$ & -2.57 & -6.52 & 2.00 & 5.17 & -1.32 & -11.89 & -1.30 \\
\hline $\begin{array}{l}\text { Number of patents } \\
\text { registered per one million } \\
\text { inhabitants }\end{array}$ & 2.00 & 5.09 & 10.78 & 13.66 & 26.88 & 59.84 & 11.39 \\
\hline $\begin{array}{l}\text { Per capita expenditures on } \\
\text { R\&D performed by } \\
\text { Government }\end{array}$ & -30.31 & -9.17 & 8.41 & -1.22 & 13.95 & -7.13 & -9.20 \\
\hline $\begin{array}{l}\text { Per capita expenditures on } \\
\text { R\&D performed by } \\
\text { Business }\end{array}$ & 6.43 & 5.51 & 5.63 & 19.93 & 5.97 & 15.14 & 7.13 \\
\hline $\begin{array}{l}\text { Employment in } \\
\text { Instrumentation and } \\
\text { Electrical Machinery per } \\
1,000 \text { employees }\end{array}$ & -5.79 & 0.70 & 17.22 & -0.81 & -1.72 & 19.13 & 4.78 \\
\hline $\begin{array}{l}\text { Employment in } \\
\text { Automotive and } \\
\text { Mechanical Engineering } \\
\text { per } 1,000 \text { employees }\end{array}$ & -8.49 & -4.96 & 6.54 & 3.65 & -2.13 & 16.60 & -0.53 \\
\hline $\begin{array}{l}\text { Employment in Biotech \& } \\
\text { Chemicals per } 1,000 \\
\text { employees }\end{array}$ & -4.07 & 0.90 & -1.40 & -12.50 & -1.50 & 10.67 & -2.05 \\
\hline $\begin{array}{l}\text { Employment in IT and } \\
\text { Computer Manufacturing } \\
\text { per } 1,000 \text { employees }\end{array}$ & -9.66 & -20.94 & -3.90 & 0.44 & -2.82 & 16.64 & -5.55 \\
\hline $\begin{array}{l}\text { Employment in High-Tech } \\
\text { Services per } 1,000 \\
\text { employees }\end{array}$ & -0.72 & 4.97 & 2.25 & 14.50 & -2.31 & 29.17 & 2.77 \\
\hline $\begin{array}{l}\text { Per capita public } \\
\text { Expenditures on Primary } \\
\text { and Secondary Education }\end{array}$ & 7.36 & 2.69 & 6.23 & 6.91 & -5.34 & 7.18 & 5.75 \\
\hline $\begin{array}{l}\text { Per capita public } \\
\text { Expenditures on Higher } \\
\text { Education }\end{array}$ & 8.03 & 11.24 & 6.17 & 5.22 & 2.56 & 35.78 & 8.76 \\
\hline
\end{tabular}


Paper\#03

\begin{tabular}{|c|c|c|c|c|c|c|c|}
\hline $\begin{array}{l}\text { Venture Capital (\$ per } \\
\text { capita) }\end{array}$ & -9.72 & 5.38 & 8.14 & 36.41 & 2.59 & 193.05 & 12.71 \\
\hline $\begin{array}{l}\text { Internet Hosts per } 1000 \\
\text { inhabitants }\end{array}$ & 10.45 & 15.80 & 31.11 & 27.07 & 27.90 & 337.03 & 39.44 \\
\hline $\begin{array}{l}\text { Secure Servers per } \\
1,000,000 \text { inhabitants }\end{array}$ & 15.70 & 18.76 & 35.19 & 27.84 & 28.96 & 317.60 & 42.55 \\
\hline $\begin{array}{l}\text { Broadband Access per } \\
1000 \text { inhabitants }\end{array}$ & 19.12 & 12.75 & 24.69 & 26.14 & 12.66 & 37.98 & 21.47 \\
\hline
\end{tabular}


Paper\#03

Table 2

Factor loadings of the variables.

\begin{tabular}{|c|c|c|c|}
\hline & $\begin{array}{l}1 \\
\text { (Fifth Wave } \\
\text { Growth) }\end{array}$ & $\begin{array}{l}2 \\
\text { (Third and } \\
\text { Fourth Wave } \\
\text { Growth) }\end{array}$ & $\begin{array}{l}3 \\
\text { (Government- } \\
\text { led Third } \\
\text { Wave Growth) }\end{array}$ \\
\hline Labor productivity & 0.20 & 0.22 & 0.20 \\
\hline Mean gross monthly earnings & -0.69 & 0.11 & -0.24 \\
\hline Economic activity rate & 0.80 & 0.45 & -0.18 \\
\hline Employment rate & 0.20 & 0.14 & 0.52 \\
\hline Number of managers per 1000 employees & -0.33 & -0.11 & 0.33 \\
\hline $\begin{array}{l}\text { Number of patents registered per one million } \\
\text { inhabitants }\end{array}$ & 0.65 & 0.53 & 0.20 \\
\hline $\begin{array}{l}\text { Per capita expenditures on R\&D performed by } \\
\text { Government }\end{array}$ & 0.00 & 0.12 & 0.73 \\
\hline $\begin{array}{l}\text { Per capita expenditures on R\&D performed by } \\
\text { Business }\end{array}$ & 0.22 & 0.34 & 0.03 \\
\hline $\begin{array}{l}\text { Employment in Instrumentation and Electrical } \\
\text { Machinery per } 1000 \text { employees }\end{array}$ & 0.06 & 0.54 & 0.64 \\
\hline $\begin{array}{l}\text { Employment in Automotive and Mechanical } \\
\text { Engineering per } 1000 \text { employees }\end{array}$ & 0.12 & 0.68 & 0.60 \\
\hline $\begin{array}{l}\text { Employment in Biotech \& Chemicals per } 1000 \\
\text { employees }\end{array}$ & 0.12 & 0.75 & 0.11 \\
\hline $\begin{array}{l}\text { Employment in IT and Computer Manufacturing per } \\
1000 \text { employees }\end{array}$ & 0.29 & 0.50 & 0.21 \\
\hline $\begin{array}{l}\text { Employment in High Tech Services per } 1000 \\
\text { employees }\end{array}$ & 0.57 & 0.36 & 0.21 \\
\hline Per capita public Expenditures on Higher Education & 0.73 & 0.36 & -0.15 \\
\hline Venture Capital ( $\$$ per capita) & 0.93 & 0.13 & 0.19 \\
\hline Internet Hosts per 1000 inhabitants & 0.90 & 0.42 & 0.08 \\
\hline
\end{tabular}

Note: Factor loadings greater than 0.40 are shown in bold and italics. 